\title{
Multidimensional Geriatric Assessment with MAGIC Questionnaire and Quality of Life in Elderly Primary Care Patients
}

\author{
Fátima Dios-Quiroga ${ }^{1, *} \mathbb{0}$, Susana Soliño-Lourido ${ }^{2}$, Carmen Pallas-Queijo ${ }^{3}$, \\ Clara González-Formoso ${ }^{3}$, Aurelia Constenla-Castro ${ }^{2}$, Soledad Conde-Freire ${ }^{4}$ \\ and Ana Clavería ${ }^{1}$ (1) \\ 1 Quality and Research Unit, Health Area of Vigo, Galician Health Service, RedIAPP, Group I-Saúde \\ (Institute of Health Research Galicia Sur), CP 36201 Vigo, Spain; anaclaveriaf@gmail.com \\ 2 Lérez Health Center, Lugar Porta do Sol s/n, Health Area of Pontevedra, CP 36156 Pontevedra, Spain; \\ aranzacity_sl@hotmail.com (S.S.-L.); mabelconstenla@yahoo.es (A.C.-C.) \\ 3 Vigo Family and Community Medicine and Nursing Teaching Unit, Health Area of Vigo, Galician Health \\ Service, RedIAPP, Group I-Saúde (Institute of Health Research Galicia Sur), CP 36201 Vigo, Spain; \\ maikapallas@gmail.com (C.P.-Q.); clara.gonzalez.formoso@sergas.es (C.G.-F.) \\ 4 Val Miñor Health Center, Avenida Portugal, 91 (A Xunqueira)—A Ramallosa, Health Area of Vigo, \\ CP 36379 Pontevedra, Spain; soledad.conde.freire@sergas.es \\ * Correspondence: fatimadiosinvest@gmail.com; Tel.: +67-885-7799
}

Received: 13 July 2020; Accepted: 23 September 2020; Published: 28 September 2020

\begin{abstract}
The Manageable Geriatric Assessment (MAGIC) questionnaire, recently developed by a group of European family doctors for multidimensional geriatric assessment in primary care, has not yet been evaluated in clinical practice. The objectives of this study were to translate and adapt it to Spanish and to check the association between the limitations of older adults identified by this questionnaire and their perceived health status assessed by the five-level version of the EuroQol-5D (EQ-5D-5L). First, questionnaire translation, back translation and cognitive test were applied. Then, a cross-sectional observational study was performed in two Spanish health centers Galicia, Spain. Participants were 170 people aged over 75, recruited opportunistically by consecutive case sampling. Anonymous surveys were used to collect data. The MAGIC questionnaire, the EQ-5D-5L scale, age and sex were employed. The visual analog scale of EQ-5D-5L (EQ VAS) was used as the outcome variable. Descriptive and bivariate analyses by sex and outcome variable are presented. The linear regression analysis showed an association with quality of life for daily activities, recognizing people and stress incontinence. As this is associated with quality of life, the MAGIC questionnaire may be useful in primary care and a study to investigate the impact on health with a clinical trial would be worth considering.
\end{abstract}

Keywords: geriatric assessment; elderly; primary care; quality of life; caring

\section{Introduction}

The pace of population aging worldwide is dramatically increasing [1]. The number of people aged 60 years and older will increase from 900 million to 2 billion by 2050 [2]. Furthermore, people over the age of 70 will spend an average of 8 years living with disabilities [3]. Although the world is rapidly moving toward an aging population, health systems do not generally fall in line with this trend. Most of the world's health services have been designed according to acute healthcare models that do not coincide with the main health problems encountered in elderly adults. This healthcare shortcoming 
is aggravated by discrimination due to age and ignores the elderly's priorities and requirements [4]. This means having to improve current health services [5].

Geriatric assessments of a preventive, proactive and evidence-based nature can help to promote health and function in the elderly [6]. Most geriatric assessments are tailored to the specific needs of institutionalized individuals and focus on function and cognition. Nevertheless, they rarely adapt to clinical practice in primary care (PC) and to older adults living in the community [7].

Morley's 2017 review [3] identified and analyzed several tools validated for use in PC to detect health problems by assessing different health domains, and even quality of life: the WHO Disability Scale (WHODAS), the Gérontopôle Fragility Screening Tool (GFST), the Two step Older persons Screening (EASYCare TOS) and the Kihon Checklist (KCL).

Despite their comprehensibility, these questionnaires are rarely used in clinical practice because lack of time makes their implementation difficult [7]. To solve this problem, the Manageable Geriatric Assessment (MAGIC) questionnaire was designed and developed by a European group of family doctors in Germany. MAGIC was developed and published in English. Its principles are to provide a brief feasible geriatric assessment adapted specially to daily PC needs. It consists of nine domains covering health problems and geriatric syndromes: everyday activities, vision, hearing, falls, urinary incontinence, immunization, depression, social support and cognitive impairment. The questionnaire enables the rapid efficient screening of relevant problems related to possible loss of autonomy in the elderly [8].

To date, no study has been carried out on using this tool in Spanish or in clinical practice. As a step prior to study its possible impact on health, we set out to check whether there is a relation between scale items and quality of life.

To this end, the objective of the present study was to translate and adapt the MAGIC questionnaire to Spanish, and to verify the association between older adult limitations identified by the questionnaire and the perceived health status assessed with the EQ VAS.

\section{Materials and Methods}

\subsection{Design and Location}

A cross-sectional observational study was carried out between 2017 and 2018 in health centers in two health areas of Galicia (Spain): Val Miñor in Vigo and Lérez in Pontevedra.

The Spanish National Health System is a system of universal coverage and public financing whose territorial organization is based on Autonomous Communities. In Galicia, with a population of 2.7 million inhabitants, there are 398 primary care centers, each with 2-10 mini-medical/nurse teams that serve an average of 1500 citizens.

\subsection{Study Population}

The study population comprised patients aged 75 or older receiving nursing care in two health centers. Patients with severe cognitive impairment according to the electronic health record (EHC) diagnosis, the inability to speak Spanish, a life expectancy of less than 1 year and/or insufficient reading ability to answer the questionnaire were excluded.

A sample size of 169 was necessary for an expected population of 300 patients in the researchers' offices, with an expected frequency of $50 \%$ in the worst case, accuracy equal to $+/-5 \%$ and an alpha risk of $95 \%$. The OpenEpi version 3 software was used.

Consecutive sampling with replacement was performed for patient recruitment, and the first three patients attending the office every day and meeting the inclusion criteria were selected. Patients self-completed the questionnaire anonymously and deposited it in an authorized box.

\subsection{Measurements}

For measurements, age, sex and data from the following scales were collected: 
- MAGIC questionnaire [8] with nine domains (daily activities, vision, hearing, falls, urinary incontinence, vaccination, depression, social environment and cognition) and 16 items: 15 categorical response items and one item that includes a question with the clock-drawing test, with scores from 1 to 7 . Except for the clock-drawing test, the other items did not score (Table 1).

Table 1. Manageable Geriatric Assessment (MAGIC) questionnaire.

\begin{tabular}{|c|c|c|c|c|}
\hline Domains & Items & Response Scale & Scoring & Direction \\
\hline Daily activities & $\begin{array}{l}\text { In the past } 2 \text { weeks: how much } \\
\text { difficulty have you had doing your } \\
\text { usual activities or tasks, both inside } \\
\text { and outside the house because of } \\
\text { your physical and emotional health? }\end{array}$ & $\begin{array}{l}\text { None, slight, some, } \\
\text { considerable or could } \\
\text { not do them }\end{array}$ & No & \\
\hline \multirow[t]{2}{*}{ Vision } & $\begin{array}{l}\text { Do you have difficulty seeing } \\
\text { newspaper print, even with glasses? }\end{array}$ & Yes or No & No & \\
\hline & $\begin{array}{l}\text { Do you have difficulty recognizing } \\
\text { people across the road, even } \\
\text { with glasses? }\end{array}$ & Yes or No & No & \\
\hline Hearing & $\begin{array}{l}\text { Do you have difficulty hearing a } \\
\text { conversation maybe even with a } \\
\text { hearing aid? }\end{array}$ & Yes or No & No & \\
\hline Falls & $\begin{array}{l}\text { Have you had a fall/falls in the last } 6 \\
\text { months? How many falls? }\end{array}$ & Less than 2 or 2 or more & No & \\
\hline \multirow[t]{2}{*}{ Urinary incontinence } & $\begin{array}{l}\text { Have you leaked urine when } \\
\text { coughing, laughing, running } \\
\text { or stooping? }\end{array}$ & $\begin{array}{l}\text { Never, Rarely, Sometimes, } \\
\text { Often or Always }\end{array}$ & No & \\
\hline & $\begin{array}{l}\text { Do you experience any leakage } \\
\text { before reaching the toilet? }\end{array}$ & $\begin{array}{l}\text { Never, Rarely, Sometimes, } \\
\text { Often or Always }\end{array}$ & No & \\
\hline \multirow{4}{*}{ Immunization } & $\begin{array}{l}\text { Have you had an influenza } \\
\text { vaccination in the last } 12 \text { months? }\end{array}$ & Yes, No or Don't Know & No & \\
\hline & $\begin{array}{l}\text { Have you had a tetanus vaccination } \\
\text { in the last } 10 \text { years? }\end{array}$ & Yes, No or Don't Know & No & \\
\hline & $\begin{array}{l}\text { Have you had a diphtheria } \\
\text { vaccination in the last } 10 \text { years? }\end{array}$ & Yes, No or Don't Know & No & \\
\hline & $\begin{array}{l}\text { Have you had a pneumococcal } \\
\text { vaccination in the last } 10 \text { years? }\end{array}$ & Yes, No or Don't Know & No & \\
\hline \multirow[t]{2}{*}{ Depression } & $\begin{array}{l}\text { In the past month, have you often } \\
\text { been bothered by feeling down, } \\
\text { depressed or hopeless? }\end{array}$ & Yes or No & No & \\
\hline & $\begin{array}{l}\text { In the past month, have you often } \\
\text { been bothered by showing little } \\
\text { interest or pleasure in doing things? }\end{array}$ & Yes or No & No & \\
\hline \multirow[t]{2}{*}{ Social environment } & $\begin{array}{l}\text { Do you have someone who would } \\
\text { be able to help you in the event of } \\
\text { an emergency? }\end{array}$ & Yes, No or Maybe & No & \\
\hline & $\begin{array}{l}\text { Do you have someone to trust and } \\
\text { confide in? }\end{array}$ & Yes, No or Maybe & No & \\
\hline Cognition & The clock-drawing test & & $1-7$ points & $\begin{array}{l}<5 \text { (Problem) or } \geq 5 \\
\quad(\text { No Problem })\end{array}$ \\
\hline
\end{tabular}

EQ-5D-5L Scale [9] (Appendix A, Figure A1). Five items, namely mobility, self-care, usual activities, pain/discomfort, anxiety/depression, had five categories each going from less to more (no problem to could not do them). One item is the patients' own assessment of their health (EQ VAS), ("patients' personal assessment of their current health" on a scale from 0 to 100). Except for EQ VAS, the five items did not score. EQ VAS was taken as the outcome variable for being a quantitative variable with a foreseeable wide range.

The study design is presented (Figure 1). 


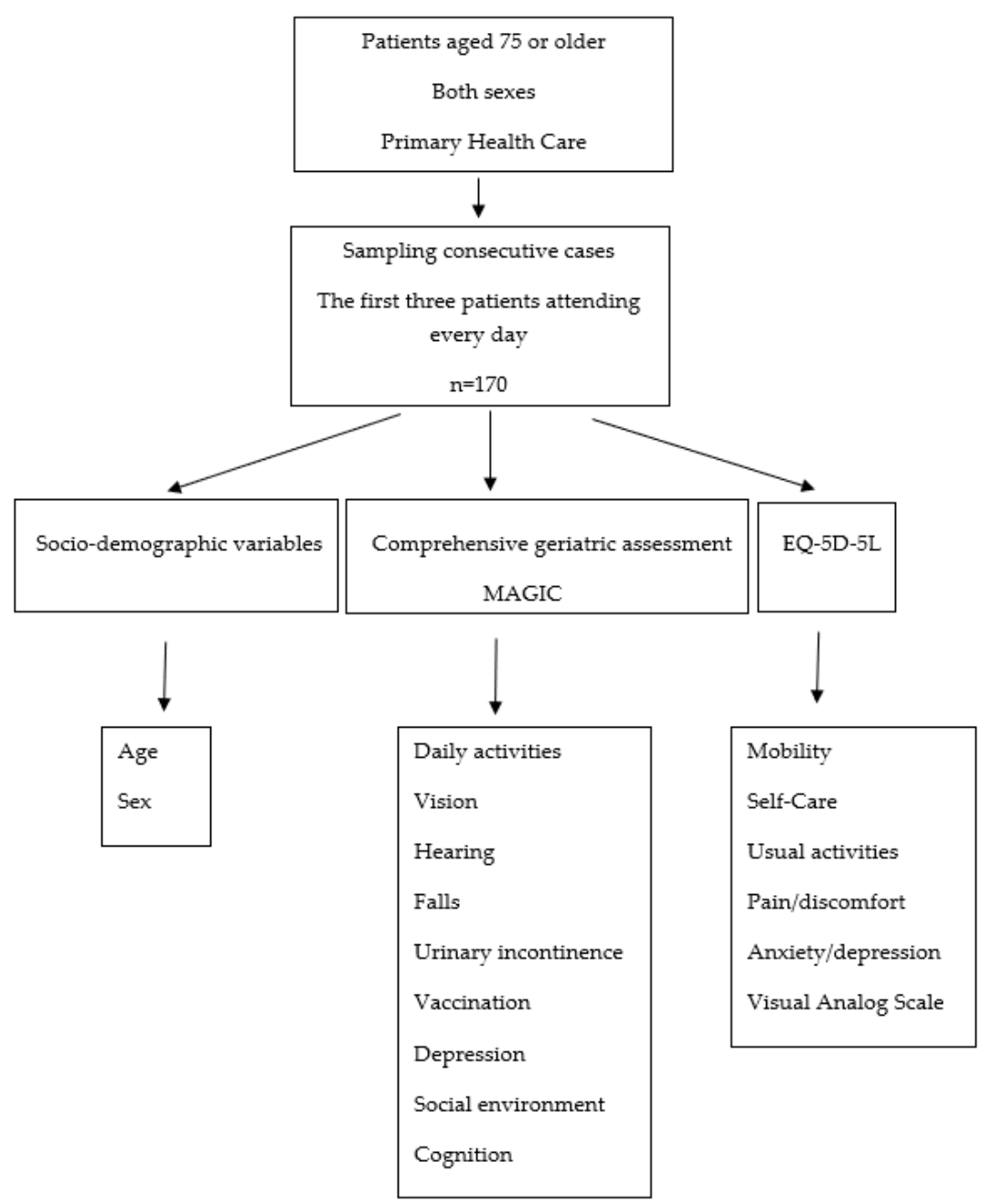

Figure 1. Study of older adults in primary care with multidimensional geriatric assessment.

\subsection{Methods}

To adapt MAGIC to our context, the translation and back-translation method was used following the International Society for Pharmacoeconomics and Outcomes Research (ISPOR) methodology [10].

- Direct translation by an official translator was followed by back translation by another professional, with assessment of equivalences following Guillemin [11] and Beaton [12];

- The wordings in some questions (Do you have someone to trust and confide in? In the past month, have you often been bothered by feeling down, depressed or hopeless? In the past month, have you often been bothered by feeling little interest or pleasure in doing things?) were compared to those used in questionnaires validated in Spanish, such as the Older Americans Resources and Services (OARS) Social Resources Scale [13], the Whooley questions [14] and the COOP/WONCA Functional Assessment Charts [15], respectively;

- Unlike the original instrument, with clock scores ranging from 1 to 7 (without specifying how it was quantified), we followed Thalmann's assessment [16]. This consists of scoring the following items: 1 point if all 12 numbers are present; 2 points if the number 12 is placed correctly; 2 points if hands are correctly proportional; 2 points if the subject is able to tell the time correctly. The optimal cut-off score was 5 points out of a total of 7;

- "Immunization" has been changed from the original MAGIC questionnaire to "vaccine" to facilitate understanding; 
- The question on pneumococcal vaccination was included as this is recommended in Galicia (Spain) [17];

- A cognitive test was performed with 10 patients over 75 years of age to check if wording and font size were acceptable.

After the translation and back translation had been completed according to the protocol, the questions about "person to trust", "depression" and "daily activities" were included using the wording from the validated scales in Spanish [13-15].

For the data analysis, a descriptive study of the MAGIC questionnaire and the EQ-5D-5L scale was carried out. Response percentages were calculated for the qualitative variables, and confidence intervals and the median/interquartile range for the quantitative ones. Nonparametric tests were used for the bivariate analysis. Linear regression was performed to analyze the adjusted association of each MAGIC questionnaire item with quality of life (measured by EQ VAS). The relation of the EQ-5D-5L items with the outcome variable was also analyzed in the same way. Automatic data preparation performed by SPSS includes measurement level adjustment, outlier and missing value handling, and supervised merging; categories that are not significantly different (that is, have a $p$-value greater than 0.1 ) are merged. SPSS v25 was employed.

This study was approved by the Clinical Research Ethics Committee of Galicia (code 2017/497).

\section{Results}

A cognitive test was performed with 10 patients, which did not lead to any modification in the proposed translation. The resulting questionnaire (MAGIC) is presented in Appendix B, Figure A2.

Of the 170 interviewed people, $62.4 \%$ with a confidence interval $(95 \% \mathrm{CI})$ from 54.9 to 69.4 were women and 37.6\% (95\% CI: 30.6-45.1) were men of a median age of 82 (interquartile range (IQR): 79-85). Three people declined to participate in the study. The time needed to complete both instruments was 15-20 min. The participants answered all the questions (100\%), except in the clock-drawing test, which six people did not answer.

The MAGIC results highlight that $15.9 \%$ (11.0-21.9) had considerable difficulty in carrying out everyday activities, 71.8\% (64.7-78.1) had no difficulties in recognizing people, 72.4\% (65.3-78.7) had no falls in the last 6 months, and 98.8\% (96.3-99.8) had someone they could trust. In the clock-drawing test, a median of 3 points was obtained with an interquartile range from 1 to 5 (Table 2). Those people who scored below 5 in the clock-drawing test came to $74.4 \%$ (67.3-80.6).

Table 2. MAGIC descriptive statistics.

\begin{tabular}{|c|c|c|c|c|c|}
\hline & & $\begin{array}{c}\mathbf{N}(\%) \\
\mathbf{N}=170 *\end{array}$ & & $6 \mathrm{C}$ & \\
\hline \multirow{5}{*}{ Daily activities } & No difficulty & $66(38.8 \%)$ & 31.7 & - & 46.3 \\
\hline & A little difficulty & $34(20.0 \%)$ & 14.5 & - & 26.5 \\
\hline & Some difficulty & $34(20.0 \%)$ & 14.5 & - & 26.5 \\
\hline & Considerable & $27(15.9 \%)$ & 11.0 & - & 21.9 \\
\hline & Could not do them & $9(5.3 \%)$ & 2.7 & - & 9.4 \\
\hline \multirow{2}{*}{ Newspaper vision } & Yes & $78(45.9 \%)$ & 38.5 & - & 53.4 \\
\hline & No & $92(54.1 \%)$ & 46.6 & - & 61.5 \\
\hline \multirow{2}{*}{ Recognizing people } & Yes & $48(28.2 \%)$ & 21.9 & - & 35.3 \\
\hline & No & $122(71.8 \%)$ & 64.7 & - & 78.1 \\
\hline
\end{tabular}


Table 2. Cont.

\begin{tabular}{|c|c|c|c|c|c|}
\hline & & $\begin{array}{c}N(\%) \\
N=170 *\end{array}$ & & $95 \% \mathrm{CI}$ & \\
\hline \multirow{2}{*}{ Hearing } & Yes & $93(54.7 \%)$ & 47.2 & - & 62.1 \\
\hline & No & $77(45.3 \%)$ & 37.9 & - & 52.8 \\
\hline \multirow{2}{*}{ Falls in the last 6 months } & Yes & $47(27.6 \%)$ & 21.3 & - & 34.7 \\
\hline & No & $123(72.4 \%)$ & 65.3 & - & 78.7 \\
\hline \multicolumn{2}{|l|}{ Number of falls } & 1.0 & 1.0 & - & 2.0 \\
\hline \multirow{5}{*}{ Stress urinary incontinence } & Never & $73(43.5 \%)$ & 36.1 & - & 51.0 \\
\hline & Rarely & $24(14.3 \%)$ & 9.6 & - & 20.2 \\
\hline & Sometimes & $40(23.8 \%)$ & 17.9 & - & 30.7 \\
\hline & Often & $20(11.9 \%)$ & 7.7 & - & 17.4 \\
\hline & Always & $11(6.5 \%)$ & 3.5 & - & 11.0 \\
\hline \multirow{5}{*}{ Urgency urinary incontinence } & Never & $67(39.9 \%)$ & 32.7 & - & 47.4 \\
\hline & Rarely & $21(12.5 \%)$ & 8.1 & - & 18.1 \\
\hline & Sometimes & $43(25.6 \%)$ & 19.5 & - & 32.6 \\
\hline & Often & $23(13.7 \%)$ & 9.1 & - & 19.5 \\
\hline & Always & $14(8.3 \%)$ & 4.9 & - & 13.2 \\
\hline \multirow{3}{*}{$\begin{array}{l}\text { An influenza vaccination in the } \\
\text { last } 12 \text { months }\end{array}$} & Yes & $148(87.1 \%)$ & 81.4 & - & 91.5 \\
\hline & No & $22(12.9 \%)$ & 8.5 & - & 18.6 \\
\hline & Don't know & 0 & & & \\
\hline \multirow{3}{*}{$\begin{array}{l}\text { A tetanus vaccination in the last } \\
10 \text { years }\end{array}$} & Yes & $81(47.6 \%)$ & 40.2 & - & 55.1 \\
\hline & No & $47(27.6 \%)$ & 21.3 & - & 34.7 \\
\hline & Don't know & $42(24.7 \%)$ & 18.7 & - & 31.6 \\
\hline \multirow{3}{*}{$\begin{array}{l}\text { A diphtheria vaccination in the } \\
\text { last } 10 \text { years }\end{array}$} & Yes & $75(44.1 \%)$ & 36.8 & - & 51.6 \\
\hline & No & $50(29.4 \%)$ & 23.0 & - & 36.6 \\
\hline & Don't know & $45(26.5 \%)$ & 20.3 & - & 33.5 \\
\hline \multirow{3}{*}{$\begin{array}{c}\text { A pneumococcal vaccination in } \\
\text { the last } 10 \text { years }\end{array}$} & Yes & $76(44.7 \%)$ & 37.4 & - & 52.2 \\
\hline & No & $43(25.3 \%)$ & 19.2 & - & 32.2 \\
\hline & Don't know & $51(30 \%)$ & 23.5 & - & 37.2 \\
\hline \multirow{2}{*}{ Depressed in the past month } & Yes & $94(55.3 \%)$ & 47.8 & - & 62.6 \\
\hline & No & $76(44.7 \%)$ & 37.4 & - & 52.2 \\
\hline \multirow{2}{*}{ Little interest doing things } & Yes & $87(51.2 \%)$ & 43.7 & - & 58.6 \\
\hline & No & $83(48.8 \%)$ & 41.4 & - & 56.3 \\
\hline \multirow{3}{*}{ Person to help in an emergency } & Yes & $156(91.8 \%)$ & 86.9 & - & 95.2 \\
\hline & No & $12(7.1 \%)$ & 3.9 & - & 11.6 \\
\hline & Maybe & $2(1.2 \%)$ & 0.2 & - & 3.7 \\
\hline \multirow{3}{*}{ Trusted person } & Yes & $168(98.8 \%)$ & 96.3 & - & 99.8 \\
\hline & No & $2(1.2 \%)$ & 0.2 & - & 3.7 \\
\hline & Maybe & 0 & & & \\
\hline \multicolumn{2}{|c|}{ Clock-drawing test (Median/IQR) } & 3 & 1.0 & - & 5.0 \\
\hline
\end{tabular}


On the EQ-5D-5L scale, 60.6\% (53.1-67.7) had no problems with bathing or dressing, and 69\% (62.1-75.9) reported pain/discomfort at varying degrees of intensity (Table 3).

Table 3. EQ-5D-5L descriptive statistics.

\begin{tabular}{|c|c|c|c|c|c|}
\hline & & $\begin{array}{c}\mathbf{N}(\%) \\
\mathbf{N}=170 *\end{array}$ & & o C & \\
\hline \multirow{5}{*}{ Mobility } & No problem & $50(29.4 \%)$ & 23.0 & - & 36.6 \\
\hline & Slight & $40(23.5 \%)$ & 17.6 & - & 30.3 \\
\hline & Moderate & $44(25.9 \%)$ & 19.7 & - & 32.8 \\
\hline & Severe & $32(18.8 \%)$ & 13.5 & - & 25.2 \\
\hline & Could not do & $4(2.4 \%)$ & 0.8 & - & 5.5 \\
\hline \multirow{5}{*}{ Self-care } & No problem & $103(60.6 \%)$ & 53.1 & - & 67.7 \\
\hline & Slight & $32(18.8 \%)$ & 13.5 & - & 25.2 \\
\hline & Moderate & $26(15.3 \%)$ & 10.5 & - & 21.3 \\
\hline & Severe & $5(2.9 \%)$ & 1.1 & - & 6.3 \\
\hline & Could not do & $4(2.4 \%)$ & 0.8 & - & 5.5 \\
\hline \multirow{5}{*}{ Usual activities } & No problem & $70(41.2 \%)$ & 34.0 & - & 48.7 \\
\hline & Slight & $49(28.8 \%)$ & 22.4 & - & 35.9 \\
\hline & Moderate & $32(18.8 \%)$ & 13.5 & - & 25.2 \\
\hline & Severe & $15(8.8 \%)$ & 5.2 & - & 13.8 \\
\hline & Could not do & $4(2.4 \%)$ & 0.8 & - & 5.5 \\
\hline \multirow{5}{*}{ Pain/discomfort } & No problem & $52(30.6 \%)$ & 24.0 & - & 37.8 \\
\hline & Slight & $48(28.2 \%)$ & 21.9 & - & 35.3 \\
\hline & Moderate & $41(24.1 \%)$ & 18.2 & - & 30.9 \\
\hline & Severe & $27(15.9 \%)$ & 11.0 & - & 21.9 \\
\hline & Extreme & $2(1.2 \%)$ & 0.2 & - & 3.7 \\
\hline \multirow{5}{*}{ Anxiety/depression } & No problem & $73(42.9 \%)$ & 35.7 & - & 50.4 \\
\hline & Slight & $42(24.7 \%)$ & 18.7 & - & 31.6 \\
\hline & Moderate & $32(18.8 \%)$ & 13.5 & - & 25.2 \\
\hline & Severe & $20(11.8 \%)$ & 7.6 & - & 17.2 \\
\hline & Extreme & $3(1.8 \%)$ & 0.5 & - & 4.6 \\
\hline \multicolumn{2}{|c|}{ EQ VAS (Median/IQR) } & 60.0 & 50.0 & - & 80.0 \\
\hline
\end{tabular}

For the outcome variable (EQ VAS), a median score of 60 was observed with an interquartile range from 50 to 80 . There were no significant differences by sex.

In the analysis by sex using MAGIC shown in Appendix C, Table A1, women were more depressed, had more cognitive impairment and more problems with stress and urge incontinence than men. Conversely, men had more hearing problems, but fewer problems with mobility when walking or doing everyday activities, and less anxiety/depression than women.

The bivariate analysis for the outcome variable showed the following to be significant: daily activities, newspaper vision, recognizing people, urge incontinence, depressed, trusted person. The results are detailed in Appendix D, Table A2. 
In the linear regression analysis, the MAGIC questionnaire variables associated with quality of life were daily activities, recognizing people and stress incontinence. The variability explained by the model was $20.6 \%$ (Table 4 ).

Table 4. Linear regression of the MAGIC questionnaire for the outcome variable (EQ VAS) *.

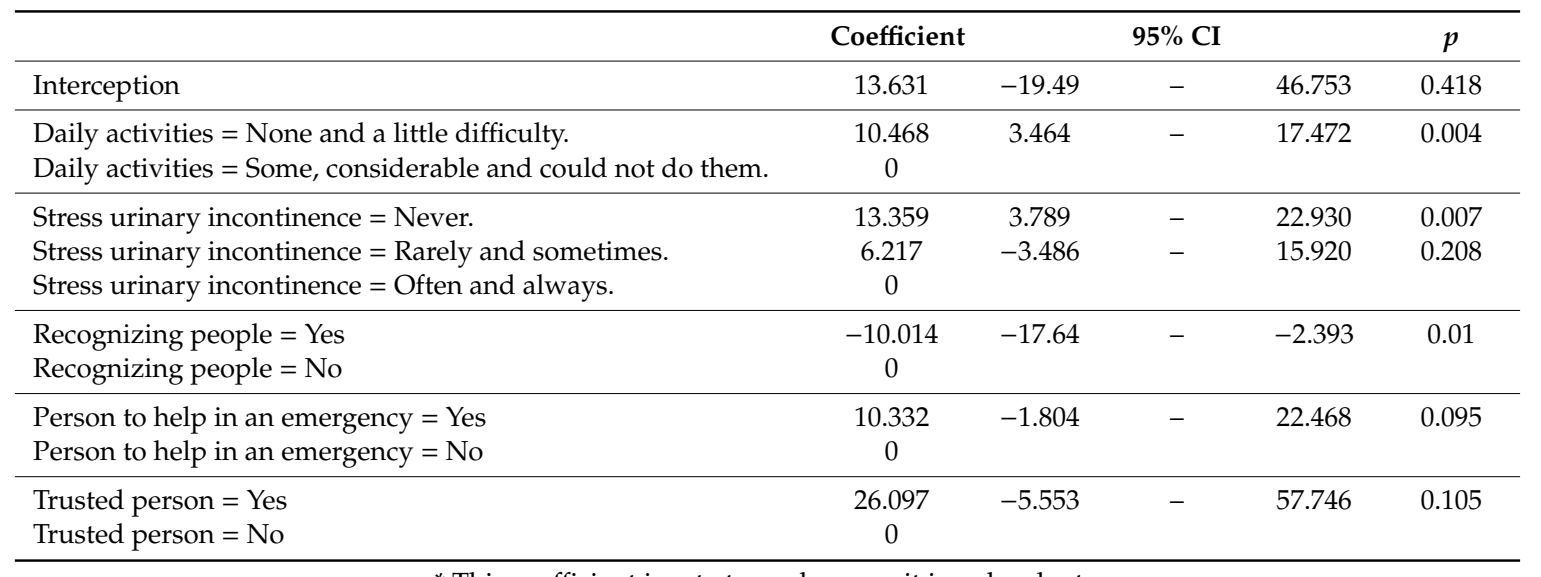

* This coefficient is set at zero because it is redundant.

A sensitivity analysis was run, in which those individuals whose impairment level was over the cut-off obtained similar results.

In the linear regression analysis, the EQ-5D-5L questionnaire variables associated with quality of life were walking mobility, anxiety/depression and pain/discomfort. The variability explained by the model was $25.5 \%$ (Table 5).

Table 5. Linear regression of the EQ-5D-5L for the outcome variable (EQ VAS) *.

\begin{tabular}{lccccc}
\hline & Coefficient & & $\mathbf{9 5 \%}$ CI & p \\
\hline Interception & 29.884 & 19.341 & - & 40.43 & 0.000 \\
\hline Mobility = No problem. & 19.658 & 9.787 & - & 29.53 & 0.000 \\
Mobility = Slight and moderate. & 12.21 & 3.617 & - & 20.8 & 0.006 \\
Mobility = Severe and could not do. & 0 & & & & 0.003 \\
\hline Anxiety/depression = No problem and slight. & 15.329 & 5.420 & - & 25.24 & 0.167 \\
Anxiety/depression = Moderate. & 8.044 & -3.398 & - & 19.46 & \\
Anxiety/depression = Severe and extreme. & 0 & & & & 0.009 \\
\hline Pain/discomfort = No problem. & 14.248 & 3.589 & - & 24.91 & 0.331 \\
Pain/discomfort = Slight and moderate. & 4.665 & -4.785 & - & 14.12 & \\
Pain/discomfort = Severe and extreme. & 0 & & & & \\
\hline
\end{tabular}

* This coefficient is set to zero because it is redundant.

Accordingly, we considered including the EQ-5D-5L questionnaire items associated with quality of life in the modified MAGIC questionnaire (MAGICm). As walking mobility and anxiety/depression are already included in daily activities and depressed, we added the pain/discomfort item (Appendix E, Figure A3).

\section{Discussion}

The MAGIC questionnaire variables with the strongest impact on quality of life were: daily activities, recognizing people and stress incontinence. These variables, therefore, indicate problems that should be inquired about and acted on as a priority in nursing practice to improve these patients' quality of life. Furthermore, Table 4 shows that the variables "having someone you can trust and in the event of an emergency" were not significant, but showed a clearly positive tendency in this direction. They could 
have been significant with a larger sample. In addition, pain came over as having an impact on quality of life and needs to be prioritized. So, we included it in the MAGICm questionnaire.

A systematic review of the scales incorporating patients' perspectives, and not only the quantification of clinical parameters assessed by professionals, shows that there is currently no instrument that comprehensively covers all the outcomes frequently sought in PC [18].

A comparison of the scales analyzed by Morley [3] revealed that the MAGIC questionnaire covers the largest number of domains as Morley mainly analyzed disability and frailty. The MAGIC questionnaire shares the assessment of everyday activities, cognition and social support with other assessed instruments. It is noteworthy that it would be interesting to assess nutritional status as measured by the WHODAS and the KCL.

In an update of preventive activities regarding older adults, when suspecting frailty, advocates multidimensional clinical assessment or comprehensive geriatric assessment (CGA) in established or more advanced cases, the 2018 recommendations of the Spanish Program for Preventive Activities and Health Promotion (PAPPS) [19] recommend confirming fragility, assessing needs and establishing adequate and individualized intervention plans. The PAPPS recommendations do not propose a specific comprehensive geriatric assessment model but advise that tests in PC should be simple and compatible with patients' usual practice. Accordingly, our study proposes a quick simple multidimensional geriatric assessment model. PAPPS recommends assessing hearing, vision, falls and cognitive impairment. These items are also included in the MAGIC questionnaire. Moreover, the aforementioned updated recommendations do not mention aspects such as incontinence, depression, among others, which have a marked effect on quality of life.

Cervantes et al. [20] analyzed the health status of older adults in PC based on a comprehensive geriatric assessment made with people aged 60 and older during five PC visits lasting 30-40 min. The variables in common with our study are vision, hearing, urinary incontinence, cognitive impairment, depression and social support. There are differences in the results obtained in both studies (e.g., $54.7 \%$ in our study had hearing problems compared to $27.7 \%$ in theirs), possibly due to the age difference between the studied populations: their study included participants from the age of 60 , while ours starts at the age of 75 . The study clearly highlights the need to create systematic health status detection programs in the PC population with timely multidisciplinary interventions by health teams to improve the quality of life of the elderly.

Compared to the Spanish National Health Survey (ENSE) [21], the observed EQ VAS was $60.38+24.11$ standard deviation (SD), while 58.56 was detected in the ENSE Spain and 58.98 in the ENSE Galicia. The similarity of the percentage distribution between both studies was considered a positive aspect because it suggests that the population was adequately sampled, despite the fact that selection was carried out through health centers rather than being population-based. For bathing and dressing, the respondents in this study aged 85 and older had fewer problems than those in the national study (no problems $40.38 \%$ vs. $47.02 \%$, respectively). Regarding walking mobility (no problems $50.14 \%$ vs. $33 \%$, respectively) and everyday activities (no problems $60.3 \%$ vs. $45.53 \%$, respectively), the respondents aged 75-84 years in the ENSE Spain had fewer problems than those in our study. For the everyday activities' variable, a high percentage of those surveyed in Spain were incapable of carrying out such activities compared to our study. No major differences appeared in the pain/discomfort comparison. In both age groups, we found that our respondents reported more anxiety/depression than the ENSE Spain respondents. The ENSE study analyzed the following socio-demographical factors: sex, age, social stratum, country of origin, level of education, economic activity and Spanish Autonomous Community. Conversely, the present study analyzed only age and sex because the purpose of the studied questionnaire was the speed with which it is completed to facilitate its use in PC. In the future, it would be interesting to analyze these other socio-demographic factors with the MAGIC questionnaire.

Liu et al. [22] conducted a systematic review about health literacy and defined it as an individual's ability to obtain and translate knowledge and information to maintain and improve health in a way that 
is appropriate to both individuals and the system. Our study did not consider this factor, but it would be worth analyzing it in the future with the HLS-EU-Q16 questionnaire [23] for information and given the importance of knowing if the people who completed the questionnaire completely understood it.

Different methodologies have been put forward to assess geriatric scales. Mueller et al. [24] carried out a prospective study with health and diagnostic measures. It concluded that the presented brief assessment tool is a useful appropriate tool for most geriatric syndromes but cannot replace a comprehensive geriatric assessment. Locatelli et al. [25] conducted a prospective study to evaluate the agreement and reliability of a geriatric assessment. These authors concluded that six of the nine geriatric assessment items described in their study had good to excellent reliability and could be safely used. We opted for a cross-sectional study with health-related quality of life as an element to confirm whether or not this is linked with questionnaire items to provide information before assessing its impact on health.

Sabbagh et al. [26] performed a study about the early detection of slight impairment in PC where the current barriers that prevent it from being suitably and accurately detected were identified. They include short visits which, in accordance with the tests that should be done, must last $10 \mathrm{~min}$ or less. The "ideal" tool that they proposed must include three critical components: cognitive evaluation by means of tasks to evaluate memory and execution; functional questionnaires; medical history. For its validation, these authors recommend studies being conducted in several languages using representative populations with slight cognitive impairment, dementia and normal cognition. The questionnaire of the present study has the advantage of being quick to complete, which means that its use in PC is feasible. Moreover, this questionnaire includes an evaluative test, the clock-drawing test, which allows us to identify those patients with slight or moderate cognitive impairment who may often be underdiagnosed so that, when they are detected, their problem can be analyzed and the subject can be informed about what interventions can be made. Finally, it was performed only by excluding serious cognitive impairment, which could entail not being able to complete the questionnaire properly, but it included slight and moderate cognitive impairment. We should remember that this study about the MAGIC questionnaire acted as a pilot study to quantify its relation with quality of life and to evaluate if, in the future, it would be interesting to analyze if significant changes in quality of life took place after detecting problems and making interventions [27]. This questionnaire allows us to know patients to detect suspected problems, including cognitive impairment, to be able to subsequently make the appropriate interventions to improve the situation with the healthcare team, including those people presenting slight or moderate impairment.

When implementing the protocol, we found that patients were highly cooperative, facilitated by its brief application. Difficulties were related mainly to drawing the clock, and several patients expressed difficulty in interpreting the wording of this item. Among the limitations, it is noteworthy that only patients from two nursing centers were selected, although the similar prevalence of the dimensions in EQ-5D-5L is indicative of its representativeness of a similar population. Thus, it would be worth extending the sample size and applying this study to other geographical areas. Another study limitation is that people with slight or moderate cognitive impairment might not properly answer the questionnaire. Finally, because the characteristics of cognitive impairment are manifested variably and heterogeneously, the clock-drawing test may not be sufficient to identify all subtypes of cognitive impairment; hence, a larger sample that would guarantee representativeness in different degrees of cognitive impairment would be appropriate.

\section{Conclusions}

After completing the study, we obtained a translated questionnaire, MAGICm, culturally adapted.

We observed that the MAGIC questionnaire was associated with quality of life. In addition, the variables that most strongly impacted quality of life were: daily activities, recognizing people and stress incontinence. These variables, therefore, indicate problems that should be inquired about and acted on as a priority in nursing practice to improve these patients' quality of life. Given its impact 
on quality of life, we believe that adding the pain/discomfort question to the initial questions on the MAGICm questionnaire is justified.

As MAGICm is associated with quality of life, a study to investigate the impact on health with a clinical trial would be worth considering to analyze if significant changes in quality of life would take place after detecting problems and making interventions.

Author Contributions: F.D.-Q. and S.S.-L. contributed substantially to the conception and design of this study. They were involved in the analysis and writing of the manuscript. C.P.-Q. and C.G.-F. contributed substantially to the conception and design of the study and participated in the critical revision of the manuscript. A.C. was involved in the design and statistical analysis and participated in the critical revision of the manuscript. A.C.-C. and S.C.-F. managed the collaboration of the health centers. All authors have read and agreed to the published version of the manuscript.

Funding: This research received no external funding.

Acknowledgments: We wish to thank the patients because without them this project would not have been possible.

Conflicts of Interest: The authors declare no conflict of interest.

\section{Appendix A}

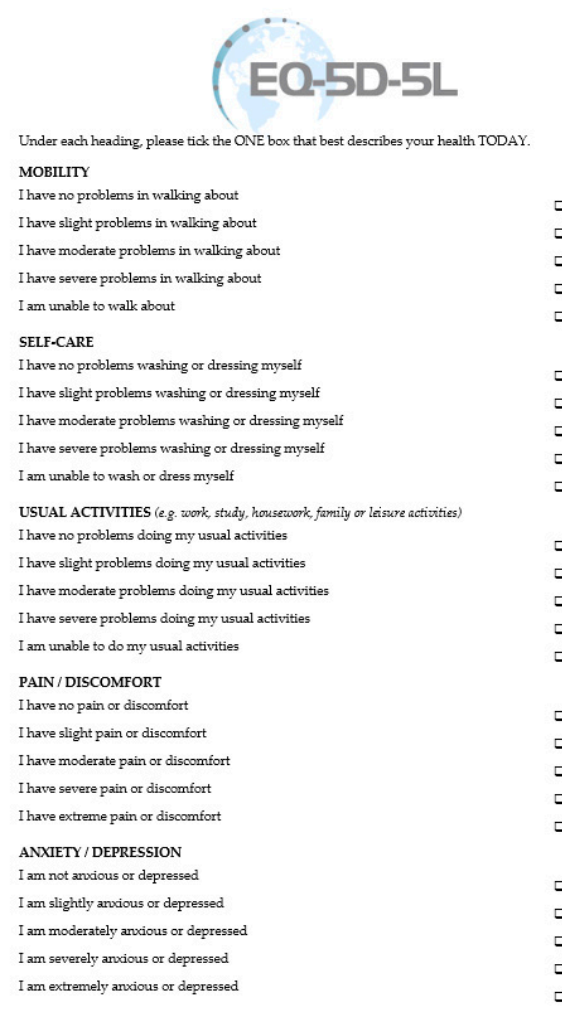

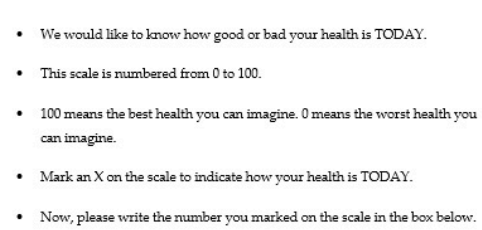

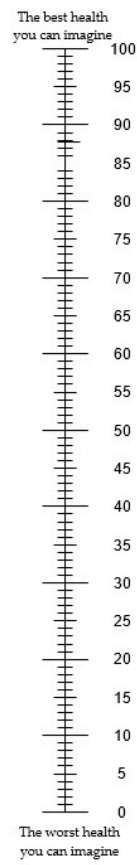

Figure A1. EQ-5D-5L. 


\section{Appendix B}

Woman $\square$ Man $\square$ Age .... years

1. In the past 2 weeks:

How much difficulty have you had doing your usual activities or tasks, both inside and outside the house because of your physical and emotional health?

2.a Do you have difficulty seeing newspaper print, even with glasses?

2.b Do you have difficulty recognizing people across the road, even with glasses?

3. Do you have difficulty hearing a conversation maybe even with a hearing aid?

4. Have you had a fall/falls in the last 6 months?, How many falls?

5.a Have you leaked urine when coughing, laughing, running or stooping?

5.b Do you experience any leakage before reaching the toilet?

6.a Have you had an influenza vaccination in the last 12 months?

6.b Have you had a tetanus vaccination in the last 10 years?

6.c Have you had a diphtheria vaccination in the last 10 years?

6.d Have you had a pneumococcal vaccination in the last 10 years?

7.a In the last month, have you often been bothered by feeling down, depressed or hopeless? 7.b In the last month, have you often been bothered by showing little interest or pleasure in doing things?

8.a Do you have someone who would be able to help you in the event of an emergency? 8.b Do you have someone to trust and confide in?

9. This is a clock. I want you to draw the missing numbers.

Afterwards please sketch in the following time. 10 minutes past 11 o' clock.

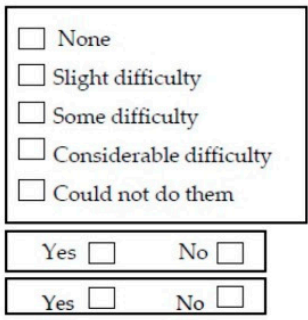

Yes $\square \quad$ No $\square$

$\square$ Less than $2 \quad \square 2$ or more

$\square$ Never
$\square$ Rarely
$\square$ Sometimes
$\square$ Often
$\square$ Always

$\square$ Never

$\square$ Rarely

$\square$ sometimes

$\square$ Often

$\square$ Always

\begin{tabular}{|l|}
\hline$\square$ Yes $\square$ No $\square$ Don't Know \\
\hline$\square$ Yes $\square$ No $\square$ Don't Know \\
\hline$\square$ Yes $\square$ No $\square$ Don't Know \\
\hline$\square$ Yes $\square$ No $\square$ Don't Know \\
\hline
\end{tabular}

\begin{tabular}{|l|}
\hline$\square$ Yes $\square$ No \\
\hline$\square$ Yes $\square$ No \\
\hline
\end{tabular}

\begin{tabular}{|l|}
\hline$\square$ Yes $\square$ No $\square$ Maybe \\
\hline$\square$ Yes $\square$ No $\square$ Maybe \\
\hline
\end{tabular}

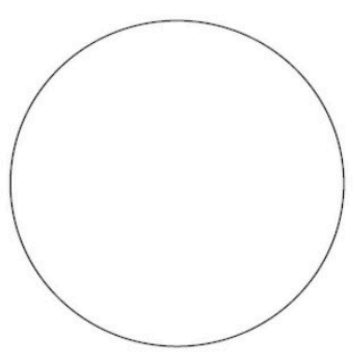

Figure A2. MAGIC. 


\section{Appendix C}

Table A1. Bivariate by sex.

\begin{tabular}{|c|c|c|c|c|c|c|c|c|c|c|c|c|c|c|c|c|}
\hline \multirow[b]{4}{*}{ Age } & & \multicolumn{14}{|c|}{ Sex } & \multirow{3}{*}{$p$} \\
\hline & & \multicolumn{7}{|c|}{ Woman } & \multicolumn{7}{|c|}{ Man } & \\
\hline & & \multirow{2}{*}{$\begin{array}{c}\mathbf{N} \\
106 \\
\end{array}$} & \multirow[t]{2}{*}{$\%$} & \multirow{2}{*}{$\begin{array}{c}\text { Lost } \\
0\end{array}$} & \multicolumn{2}{|c|}{ Median } & \multicolumn{2}{|c|}{ IQR * } & \multirow{2}{*}{$\begin{array}{l}\mathbf{N} \\
64 \\
\end{array}$} & \multirow[t]{2}{*}{$\%$} & \multirow{2}{*}{$\begin{array}{c}\text { Lost } \\
0\end{array}$} & \multicolumn{2}{|c|}{ Median } & \multicolumn{2}{|l|}{ IQR * } & \\
\hline & & & & & 82.0 & 79.0 & - & 85.0 & & & & 81.0 & 77.5 & - & 85.0 & 0.268 \\
\hline \multirow{5}{*}{ Daily activities } & No difficulty & 34 & 32.1 & & & 23.8 & - & 41.4 & 32 & 50.0 & & & 38.0 & - & 62.0 & 0.130 \\
\hline & Slight difficulty & 24 & 22.6 & & & 15.5 & - & 31.3 & 10 & 15.6 & & & 8.3 & - & 25.9 & \\
\hline & Some difficulty & 22 & 20.8 & & & 13.9 & - & 29.2 & 12 & 18.8 & & & 10.7 & - & 29.6 & \\
\hline & Considerable & 19 & 17.9 & & & 11.5 & - & 26.0 & 8 & 12.5 & & & 6.1 & - & 22.2 & \\
\hline & Could not do them & 7 & 6.6 & & & 3.0 & - & 12.5 & 2 & 3.1 & & & 0.7 & - & 9.6 & \\
\hline \multirow{2}{*}{ Newspaper vision } & Yes & 47 & 44.3 & & & 35.1 & - & 53.8 & 31 & 48.4 & & & 36.5 & - & 60.5 & 0.611 \\
\hline & No & 59 & 55.7 & & & 46.2 & - & 64.9 & 33 & 51.6 & & & 39.5 & - & 63.5 & \\
\hline \multirow{2}{*}{ Recognizing people } & Yes & 31 & 29.2 & & & 21.2 & - & 38.4 & 17 & 26.6 & & & 16.9 & - & 38.2 & 0.632 \\
\hline & No & 75 & 70.8 & & & 61.6 & - & 78.8 & 47 & 73.4 & & & 61.8 & - & 83.1 & \\
\hline \multirow{2}{*}{ Hearing } & Yes & 51 & 48.1 & & & 38.8 & - & 57.6 & 42 & 65.6 & & & 53.5 & - & 76.4 & 0.039 \\
\hline & No & 55 & 51.9 & & & 42.4 & - & 61.2 & 22 & 34.4 & & & 23.6 & - & 46.5 & \\
\hline \multirow{2}{*}{ Falls in the last 6 months } & Yes & 34 & 32.1 & & & 23.8 & - & 41.4 & 13 & 20.3 & & & 11.9 & - & 31.3 & 0.122 \\
\hline & No & 72 & 67.9 & & & 58.6 & - & 76.2 & 51 & 79.7 & & & 68.7 & - & 88.1 & \\
\hline \multicolumn{2}{|c|}{ Number of falls } & 106 & & 72 & 1.0 & 1.0 & - & 2.0 & 64 & & 51 & 2.0 & 1.0 & - & 2.0 & 0.680 \\
\hline \multirow{5}{*}{ Stress urinary incontinence } & Never & 34 & 32.1 & & & 23.8 & - & 41.4 & 39 & 62.9 & & & 50.5 & - & 74.1 & 0.000 \\
\hline & Rarely & 14 & 13.2 & & & 7.8 & - & 20.6 & 10 & 16.1 & & & 8.6 & - & 26.7 & \\
\hline & Sometimes & 30 & 28.3 & & & 20.4 & - & 37.4 & 10 & 16.1 & & & 8.6 & - & 26.7 & \\
\hline & Often & 18 & 17.0 & & & 10.8 & - & 25.0 & 2 & 3.2 & & & 0.7 & - & 9.9 & \\
\hline & Always & 10 & 9.4 & & & 5.0 & - & 16.1 & 1 & 1.6 & & & 0.2 & - & 7.3 & \\
\hline \multirow{5}{*}{ Urgency urinary incontinence } & Never & 31 & 29.2 & & & 21.2 & - & 38.4 & 36 & 58.1 & & & 45.6 & - & 69.7 & 0.001 \\
\hline & Rarely & 13 & 12.3 & & & 7.1 & - & 19.5 & 8 & 12.9 & & & 6.3 & - & 22.9 & \\
\hline & Sometimes & 30 & 28.3 & & & 20.4 & - & 37.4 & 13 & 21.0 & & & 12.3 & - & 32.3 & \\
\hline & Often & 21 & 19.8 & & & 13.1 & - & 28.2 & 2 & 3.2 & & & 0.7 & - & 9.9 & \\
\hline & Always & 11 & 10.4 & & & 5.6 & - & 17.2 & 3 & 4.8 & & & 1.4 & - & 12.4 & \\
\hline
\end{tabular}


Table A1. Cont.

\begin{tabular}{|c|c|c|c|c|c|c|c|c|c|c|c|c|c|c|c|c|}
\hline & & \multicolumn{14}{|c|}{ Sex } & \multirow{3}{*}{$p$} \\
\hline & & \multicolumn{7}{|c|}{ Woman } & \multicolumn{7}{|c|}{ Man } & \\
\hline & & $\mathbf{N}$ & $\%$ & Lost & Medi & & IQR * & & $\mathbf{N}$ & $\%$ & Lost & Medi & & IQR * & & \\
\hline \multirow{3}{*}{$\begin{array}{l}\text { An influenza vaccination in the } \\
\text { last } 12 \text { months }\end{array}$} & Yes & 92 & 86.8 & & & 79.4 & - & 92.2 & 56 & 87.5 & & & 77.8 & - & 93.9 & 0.955 \\
\hline & No & 14 & 13.2 & & & 7.8 & - & 20.6 & 8 & 12.5 & & & 6.1 & - & 22.2 & \\
\hline & Don't know & 0 & 0.0 & & & & - & & 0 & 0.0 & & & & - & & \\
\hline \multirow{3}{*}{$\begin{array}{l}\text { A tetanus vaccination in the } \\
\text { last } 10 \text { years }\end{array}$} & Yes & 50 & 47.2 & & & 37.8 & - & 56.6 & 31 & 48.4 & & & 36.5 & - & 60.5 & 0.444 \\
\hline & No & 33 & 31.1 & & & 22.9 & - & 40.4 & 14 & 21.9 & & & 13.1 & - & 33.1 & \\
\hline & Don't know & 23 & 21.7 & & & 14.7 & - & 30.2 & 19 & 29.7 & & & 19.6 & - & 41.6 & \\
\hline \multirow{3}{*}{$\begin{array}{l}\text { A diphtheria vaccination in the } \\
\text { last } 10 \text { years }\end{array}$} & Yes & 46 & 43.4 & & & 34.2 & - & 52.9 & 29 & 45.3 & & & 33.5 & - & 57.5 & 0.689 \\
\hline & No & 34 & 32.1 & & & 23.8 & - & 41.4 & 16 & 25.0 & & & 15.7 & - & 36.5 & \\
\hline & Don't know & 26 & 24.5 & & & 17.1 & - & 33.3 & 19 & 29.7 & & & 19.6 & - & 41.6 & \\
\hline \multirow{3}{*}{$\begin{array}{c}\text { A pneumococcal vaccination in } \\
\text { the last } 10 \text { years }\end{array}$} & Yes & 48 & 45.3 & & & 36.0 & - & 54.8 & 28 & 43.8 & & & 32.1 & - & 56.0 & 0.242 \\
\hline & No & 31 & 29.2 & & & 21.2 & - & 38.4 & 12 & 18.8 & & & 10.7 & - & 29.6 & \\
\hline & Don't know & 27 & 25.5 & & & 17.9 & - & 34.3 & 24 & 37.5 & & & 26.4 & - & 49.7 & \\
\hline \multirow{2}{*}{ Depressed in the past month } & Yes & 65 & 61.3 & & & 51.8 & - & 70.2 & 29 & 45.3 & & & 33.5 & - & 57.5 & 0.026 \\
\hline & No & 41 & 38.7 & & & 29.8 & - & 48.2 & 35 & 54.7 & & & 42.5 & - & 66.5 & \\
\hline \multirow{2}{*}{ Little interest in doing things } & Yes & 56 & 52.8 & & & 43.4 & - & 62.2 & 31 & 48.4 & & & 36.5 & - & 60.5 & 0.449 \\
\hline & No & 50 & 47.2 & & & 37.8 & - & 56.6 & 33 & 51.6 & & & 39.5 & - & 63.5 & \\
\hline \multirow{3}{*}{ Person to help in an emergency } & Yes & 96 & 90.6 & & & 83.9 & - & 95.0 & 60 & 93.8 & & & 85.8 & - & 97.9 & 0.600 \\
\hline & No & 9 & 8.5 & & & 4.3 & - & 14.9 & 3 & 4.7 & & & 1.3 & - & 12.0 & \\
\hline & Maybe & 1 & 0.9 & & & 0.1 & - & 4.3 & 1 & 1.6 & & & 0.2 & - & 7.1 & \\
\hline \multirow{3}{*}{ Trusted person } & Yes & 104 & 98.1 & & & 94.1 & - & 99.6 & 64 & 100.0 & & & & - & & 0.532 \\
\hline & No & 2 & 1.9 & & & 0.4 & - & 5.9 & 0 & 0.0 & & & & - & & \\
\hline & Maybe & 0 & 0.0 & & & & - & & 0 & 0.0 & & & & - & & \\
\hline \multicolumn{2}{|c|}{ Clock-drawing test } & 106 & & 2 & 2.0 & 0.0 & - & 3.0 & 64 & & 4 & 3.0 & 1.5 & - & 7.0 & 0.009 \\
\hline \multirow{5}{*}{ Mobility } & No problem & 24 & 22.6 & & & 15.5 & - & 31.3 & 26 & 40.6 & & & 29.2 & - & 52.9 & 0.048 \\
\hline & Slight & 26 & 24.5 & & & 17.1 & - & 33.3 & 14 & 21.9 & & & 13.1 & - & 33.1 & \\
\hline & Moderate & 29 & 27.4 & & & 19.6 & - & 36.4 & 15 & 23.4 & & & 14.4 & - & 34.8 & \\
\hline & Severe & 24 & 22.6 & & & 15.5 & - & 31.3 & 8 & 12.5 & & & 6.1 & - & 22.2 & \\
\hline & Could not do & 3 & 2.8 & & & 0.8 & - & 7.4 & 1 & 1.6 & & & 0.2 & - & 7.1 & \\
\hline
\end{tabular}


Table A1. Cont.

\begin{tabular}{|c|c|c|c|c|c|c|c|c|c|c|c|c|c|c|c|c|}
\hline & & \multicolumn{14}{|c|}{ Sex } & \multirow{3}{*}{$p$} \\
\hline & & \multicolumn{7}{|c|}{ Woman } & \multicolumn{7}{|c|}{ Man } & \\
\hline & & $\mathbf{N}$ & $\%$ & Lost & Medi & & IQR * & & $\mathbf{N}$ & $\%$ & Lost & Medi & & IQR * & & \\
\hline \multirow{5}{*}{ Self-care } & No problem & 59 & 55.7 & & & 46.2 & - & 64.9 & 44 & 68.8 & & & 56.8 & - & 79.1 & 0.302 \\
\hline & Slight & 24 & 22.6 & & & 15.5 & - & 31.3 & 8 & 12.5 & & & 6.1 & - & 22.2 & \\
\hline & Moderate & 18 & 17.0 & & & 10.8 & - & 25.0 & 8 & 12.5 & & & 6.1 & - & 22.2 & \\
\hline & Severe & 3 & 2.8 & & & 0.8 & - & 7.4 & 2 & 3.1 & & & 0.7 & - & 9.6 & \\
\hline & Could not do & 2 & 1.9 & & & 0.4 & - & 5.9 & 2 & 3.1 & & & 0.7 & - & 9.6 & \\
\hline \multirow{5}{*}{ Usual activities } & No problem & 36 & 34.0 & & & 25.5 & - & 43.3 & 34 & 53.1 & & & 41.0 & - & 65.0 & 0.014 \\
\hline & Slight & 33 & 31.1 & & & 22.9 & - & 40.4 & 16 & 25.0 & & & 15.7 & - & 36.5 & \\
\hline & Moderate & 21 & 19.8 & & & 13.1 & - & 28.2 & 11 & 17.2 & & & 9.5 & - & 27.8 & \\
\hline & Severe & 14 & 13.2 & & & 7.8 & - & 20.6 & 1 & 1.6 & & & 0.2 & - & 7.1 & \\
\hline & Could not do & 2 & 1.9 & & & 0.4 & - & 5.9 & 2 & 3.1 & & & 0.7 & - & 9.6 & \\
\hline \multirow{5}{*}{ Pain/discomfort } & No problem & 27 & 25.5 & & & 17.9 & - & 34.3 & 25 & 39.1 & & & 27.8 & - & 51.3 & 0.250 \\
\hline & Slight & 29 & 27.4 & & & 19.6 & - & 36.4 & 19 & 29.7 & & & 19.6 & - & 41.6 & \\
\hline & Moderate & 29 & 27.4 & & & 19.6 & - & 36.4 & 12 & 18.8 & & & 10.7 & - & 29.6 & \\
\hline & Severe & 19 & 17.9 & & & 11.5 & - & 26.0 & 8 & 12.5 & & & 6.1 & - & 22.2 & \\
\hline & Extreme & 2 & 1.9 & & & 0.4 & - & 5.9 & 0 & 0.0 & & & & - & & \\
\hline \multirow{5}{*}{ Anxiety/depression } & No problem & 36 & 34.0 & & & 25.5 & - & 43.3 & 37 & 57.8 & & & 45.6 & - & 69.3 & 0.005 \\
\hline & Slight & 29 & 27.4 & & & 19.6 & - & 36.4 & 13 & 20.3 & & & 11.9 & - & 31.3 & \\
\hline & Moderate & 20 & 18.9 & & & 12.3 & - & 27.1 & 12 & 18.8 & & & 10.7 & - & 29.6 & \\
\hline & Severe & 18 & 17.0 & & & 10.8 & - & 25.0 & 2 & 3.1 & & & 0.7 & - & 9.6 & \\
\hline & Extreme & 3 & 2.8 & & & 0.8 & - & 7.4 & 0 & 0.0 & & & & - & & \\
\hline EQ VAS & & 106 & & 0 & 60.0 & 50.0 & - & 80.0 & 64 & & 0 & 60.0 & 50.0 & - & 80.0 & 0.446 \\
\hline
\end{tabular}

${ }^{*}$ Interquartile range. 


\section{Appendix D}

Table A2. The bivariate analysis for the outcome variable.

\begin{tabular}{|c|c|c|c|c|c|c|c|}
\hline & & $\mathbf{N}$ & Median & & IQR * & & $p$ \\
\hline \multirow{5}{*}{ Daily activities } & No difficulty & 66 & 73 & 50 & - & 90 & 0.000 \\
\hline & Slight difficulty & 34 & 60 & 50 & - & 70 & \\
\hline & Some difficulty & 34 & 50 & 35 & - & 70 & \\
\hline & Considerable & 27 & 50 & 40 & - & 60 & \\
\hline & Could not do them & 9 & 50 & 30 & - & 70 & \\
\hline \multirow{2}{*}{ Newspaper vision } & Yes & 78 & 50 & 40 & - & 75 & 0.005 \\
\hline & No & 92 & 70 & 50 & - & 80 & \\
\hline \multirow{2}{*}{ Recognizing people } & Yes & 48 & 50 & 30 & - & 70 & 0.000 \\
\hline & No & 122 & 63 & 50 & - & 80 & \\
\hline \multirow{2}{*}{ Hearing } & Yes & 93 & 60 & 50 & - & 80 & 0.398 \\
\hline & No & 77 & 60 & 40 & - & 75 & \\
\hline \multirow{2}{*}{ Falls in the last 6 months } & Yes & 47 & 50 & 35 & - & 80 & 0.093 \\
\hline & No & 123 & 60 & 50 & - & 80 & \\
\hline \multirow{5}{*}{ Stress urinary incontinence } & Never & 73 & 70 & 50 & - & 85 & 0.005 \\
\hline & Rarely & 24 & 60 & 50 & - & 80 & \\
\hline & Sometimes & 40 & 55 & 50 & - & 78 & \\
\hline & Often & 20 & 50 & 30 & - & 60 & \\
\hline & Always & 11 & 50 & 30 & - & 80 & \\
\hline \multirow{5}{*}{ Urgency urinary incontinence } & Never & 67 & 70 & 50 & - & 80 & 0.049 \\
\hline & Rarely & 21 & 50 & 50 & - & 60 & \\
\hline & Sometimes & 43 & 60 & 50 & - & 80 & \\
\hline & Often & 23 & 50 & 30 & - & 70 & \\
\hline & Always & 14 & 70 & 30 & - & 90 & \\
\hline \multirow{3}{*}{$\begin{array}{l}\text { An influenza vaccination in the last } \\
\qquad 12 \text { months }\end{array}$} & Yes & 148 & 60 & 50 & - & 80 & 0.402 \\
\hline & No & 22 & 65 & 50 & - & 85 & \\
\hline & Don't know & 0 & . & . & - & 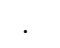 & \\
\hline \multirow{3}{*}{$\begin{array}{l}\text { A tetanus vaccination in the last } \\
\qquad 10 \text { years }\end{array}$} & Yes & 81 & 60 & 50 & - & 80 & 0.850 \\
\hline & No & 47 & 60 & 50 & - & 80 & \\
\hline & Don't know & 42 & 60 & 50 & - & 80 & \\
\hline \multirow{3}{*}{$\begin{array}{l}\text { A diphtheria vaccination in the last } \\
\qquad 10 \text { years }\end{array}$} & Yes & 75 & 60 & 50 & - & 80 & 0.880 \\
\hline & No & 50 & 60 & 50 & - & 80 & \\
\hline & Don't know & 45 & 60 & 50 & - & 80 & \\
\hline \multirow{3}{*}{$\begin{array}{l}\text { A pneumococcal vaccination in the } \\
\text { last } 10 \text { years }\end{array}$} & Yes & 76 & 60 & 50 & - & 80 & 0.440 \\
\hline & No & 43 & 70 & 50 & - & 90 & \\
\hline & Don't know & 51 & 60 & 50 & - & 75 & \\
\hline \multirow{2}{*}{ Depressed in the past month } & Yes & 94 & 50 & 40 & - & 75 & 0.014 \\
\hline & No & 76 & 65 & 50 & - & 80 & \\
\hline \multirow{2}{*}{ Little interest in doing things } & Yes & 87 & 55 & 40 & - & 80 & 0.089 \\
\hline & No & 83 & 60 & 50 & - & 80 & \\
\hline \multirow{3}{*}{ Person to help in an emergency } & Yes & 156 & 60 & 50 & - & 80 & 0.055 \\
\hline & No & 12 & 50 & 30 & - & 60 & \\
\hline & Maybe & 2 & 43 & 35 & - & 50 & \\
\hline \multirow{3}{*}{ Trusted person } & Yes & 168 & 60 & 50 & - & 80 & 0.014 \\
\hline & No & 2 & 15 & 0 & - & 30 & \\
\hline & Maybe & 0 & . & . & - & . & \\
\hline \multirow{5}{*}{ Mobility } & No problem & 50 & 75 & 60 & - & 90 & 0.000 \\
\hline & Slight & 40 & 60 & 50 & - & 80 & \\
\hline & Moderate & 44 & 60 & 50 & - & 70 & \\
\hline & Severe & 32 & 45 & 30 & - & 65 & \\
\hline & Could not do & 4 & 30 & 30 & - & 40 & \\
\hline \multirow{5}{*}{ Self-care } & No problem & 103 & 60 & 50 & - & 80 & 0.005 \\
\hline & Slight & 32 & 60 & 50 & - & 80 & \\
\hline & Moderate & 26 & 50 & 35 & - & 80 & \\
\hline & Severe & 5 & 30 & 20 & - & 50 & \\
\hline & Could not do & 4 & 35 & 30 & - & 45 & \\
\hline
\end{tabular}


Table A2. Cont.

\begin{tabular}{|c|c|c|c|c|c|c|c|}
\hline & & $\mathbf{N}$ & Median & & IQR * & & $p$ \\
\hline \multirow{5}{*}{ Usual activities } & No problem & 70 & 70 & 55 & - & 80 & 0.000 \\
\hline & Slight & 49 & 60 & 50 & - & 80 & \\
\hline & Moderate & 32 & 50 & 38 & - & 70 & \\
\hline & Severe & 15 & 40 & 30 & - & 50 & \\
\hline & Could not do & 4 & 30 & 20 & - & 40 & \\
\hline \multirow{5}{*}{ Pain/discomfort } & No problem & 52 & 80 & 50 & - & 90 & 0.000 \\
\hline & Slight & 48 & 60 & 50 & - & 80 & \\
\hline & Moderate & 41 & 60 & 50 & - & 65 & \\
\hline & Severe & 27 & 50 & 30 & - & 55 & \\
\hline & Extreme & 2 & 30 & 30 & - & 30 & \\
\hline \multirow{5}{*}{ Anxiety/depression } & No problem & 73 & 60 & 50 & - & 80 & 0.000 \\
\hline & Slight & 42 & 70 & 50 & - & 80 & \\
\hline & Moderate & 32 & 50 & 45 & - & 70 & \\
\hline & Severe & 20 & 40 & 30 & - & 58 & \\
\hline & Extreme & 3 & 35 & 30 & - & 40 & \\
\hline
\end{tabular}

${ }^{*}$ Interquartile range.

\section{Appendix E}

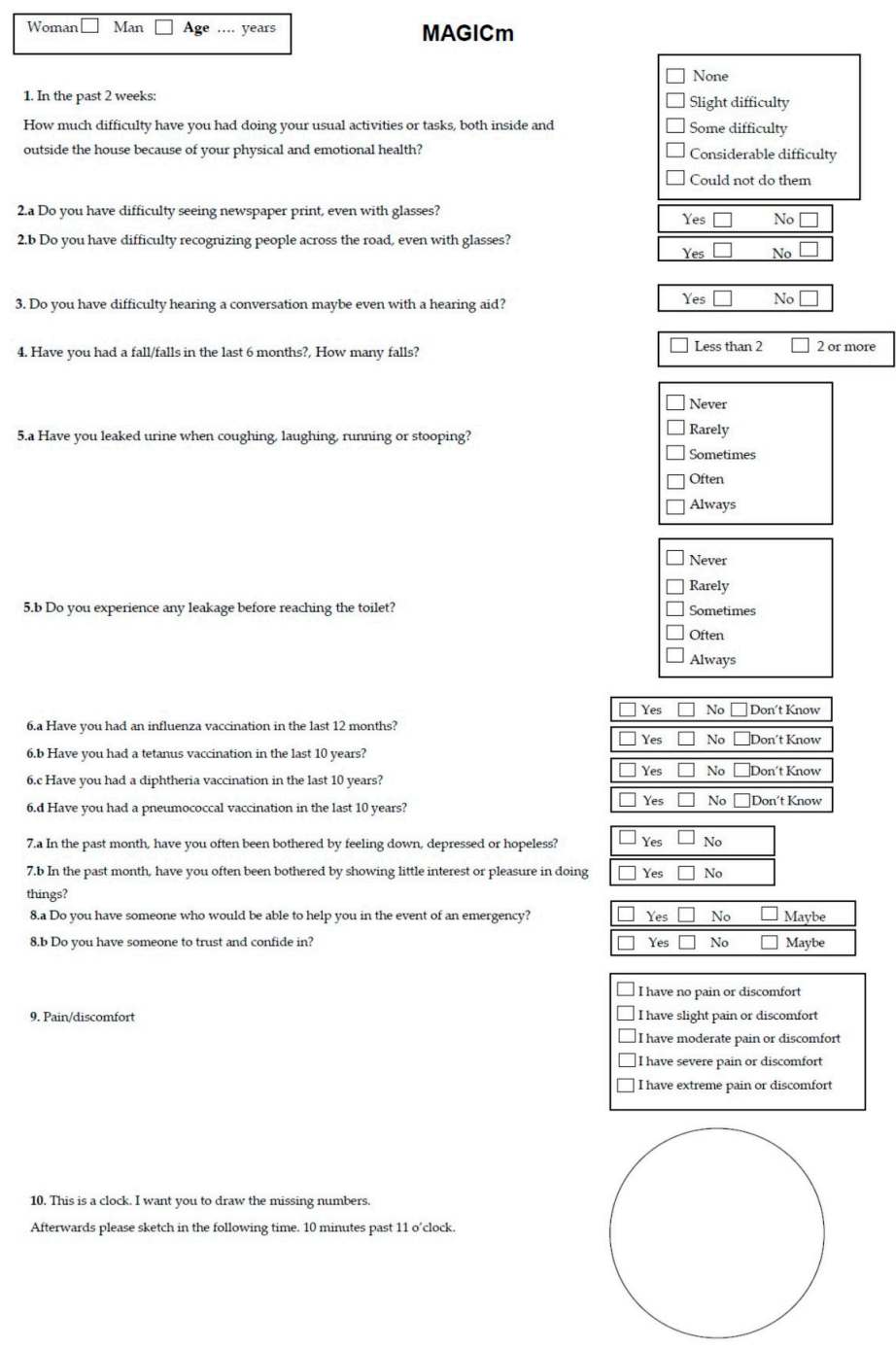

Figure A3. MAGICm. 


\section{References}

1. World Health Organization. Ageing and Health. Available online: https://www.who.int/news-room/factsheets/detail/ageing-and-health/ (accessed on 5 February 2018).

2. Baraković, S.; Baraković Husić, J.; van Hoof, J.; Krejcar, O.; Maresova, P.; Akhtar, Z.; Melero, F.J. Quality of Life Framework for Personalised Ageing: A Systematic Review of ICT Solutions. Int. J. Environ. Res. Public Health 2020, 17, 2940. [CrossRef]

3. Morley, J.E.; Arai, H.; Cao, L.; Dong, B.; Merchant, R.A.; Vellas, B.; Visvanathan, R.; Woo, J. Integrated Care: Enhancing the Role of the Primary Health Care Professional in Preventing Functional Decline: A Systematic Review. J. Am. Med. Dir. Assoc. 2017, 18, 489-494. [CrossRef] [PubMed]

4. OMS. Informe Mundial Sobre El Envejecimiento y La Salud; OMS: Nueva York, NY, USA, 2015; pp. $100-131$.

5. Boeckxstaens, P.; Graff, P. International Exchange Primary Care and Care for Older Persons: Position Paper of the European Forum for Primary Care. Qual. Prim. Care 2011, 19, 369-389. [PubMed]

6. Sandholzer, H.; Hellenbrand, W.; Renteln-Kruse, W.; Van Weel, C.; Walker, P. STEP_Europäische Leitlinie Für Das Standardisierte Evidenzbasierte Präventive Assessment Älterer Menschen in Der Medizinischen Primärversorgung. DMW-Dtsch. Med. Wochenschr. 2004, 129, S183-S226. [CrossRef] [PubMed]

7. Seematter-Bagnoud, L.; Büla, C. Brief Assessments and Screening for Geriatric Conditions in Older Primary Care Patients: A Pragmatic Approach. Public Health Rev. 2018, 39, 1-13. [CrossRef]

8. Barkhausen, T.; Junius-Walker, U.; Hummers-Pradier, E.; Mueller, C.A.; Theile, G. "It's MAGIC"-Development of a Manageable Geriatric Assessment for General Practice Use. BMC Fam. Pract. 2015, 16, 4. [CrossRef]

9. EuroQol Research Foundation. EQ-5D-5L User Guide. 2019. Available online: https://euroqol.org/ publications/user-guides (accessed on 15 September 2020).

10. Wild, D.; Grove, A.; Martin, M.; Eremenco, S.; McElroy, S.; Verjee-Lorenz, A.; Erikson, P.; ISPOR Task Force for Translation and Cultural Adaptation. Principles of Good Practice for the Translation and Cultural Adaptation Process for Patient-Reported Outcomes (PRO) Measures: Report of the ISPOR Task Force for Translation and Cultural Adaptation. Value Health 2005, 8, 94-104. [CrossRef]

11. Guillemin, F.; Bombardier, C.; Beaton, D. Cross-Cultural Adaptation of Health-Related Quality of Life Measures: Literature Review and Proposed Guidelines. J. Clin. Epidemiol. 1993, 46, 1417-1432. [CrossRef]

12. Beaton, D.E.; Bombardier, C.; Guillemin, F.; Ferraz, M.B. Guidelines for the Process of Cross-Cultural Adaptation of Self-Report Measures. Spine 2000, 25, 3186-3191. [CrossRef]

13. Grau Fibla, G.; Eiroa Patiño, P.; Cayuela Domínguez, A. Spanish Version of the OARS Multidimensional Functional Assessment Questionnaire: Cross-Cultural Adaptation and Validity Measurement. Atencion Primaria 1996, 17, 486-495.

14. Whooley, M.A.; Avins, A.L.; Miranda, J.; Browner, W.S. Case-Finding Instruments for Depression. Two Questions Are as Good as Many. J. Gen. Intern. Med. 1997, 12, 439-445. [CrossRef] [PubMed]

15. López Alonso, S.R.; Martínez Sánchez, C.M.; Romero Cañadillas, A.B.; Angel Rueda, M. Validez y Fiabilidad Del Cuestionario COOP/WONCA Cumplimentado Vía Telefónica En Personas Con Artrosis de Cadera y Rodilla. Index de Enfermería 2005, 14, 24-28. [CrossRef]

16. Thalmann, B.; Spiegel, R.; Stähelin, H.B. Dementia Screening in General Practice: Optimised Scoring for the Clock Drawing Test. Brain Aging Int. J. 2002, 2, 36-43.

17. Grupo de trabajo vacunación frente a neumococo en grupos de riesgo 2015 de la Ponencia de Programas y Registro de Vacunaciones. In Utilización de la Vacuna Frente a Neumococo en Grupos de Riesgo; Comisión de Salud Pública del Consejo Interterritorial del Sistema Nacional de Salud; Ministerio de Sanidad, Servicios Sociales e Igualdad: Madrid, Spain, 2015.

18. Murphy, M.; Hollinghurst, S.; Salisbury, C. Identification, Description and Appraisal of Generic PROMs for Primary Care: A Systematic Review. BMC Fam. Pract. 2018, 19, 1-12. [CrossRef] [PubMed]

19. Hoyos Alonso, M.C.; Gorroñogoitia Iturbe, A.; Martín Lesende, I.; Baena Díez, J.M.; López-Torres Hidalgo, J.; Magán Tapia, P.; Acosta Benito, M.Á.; Herreros Herreros, Y. Actividades Preventivas En Los Mayores. Actualización PAPPS 2018. Atención Primaria 2018, 50, 109-124. [CrossRef]

20. Cervantes Becerra, R.G.; Villarreal Ríos, E.; Galicia Rodríguez, L.; Vargas Daza, E.R.; Martínez González, L. Estado de Salud En El Adulto Mayor En Atención Primaria a Partir de Una Valoración Geriátrica Integral. Atención Primaria 2015, 47, 329-335. [CrossRef] 
21. Suárez Cardona, M.; Neira León, M.; Pastor Sanz, M.T.; De los Santos Ichaso Hernàndez-Rubio, M. Encuesta Nacional De Salud Serie 2011/2012; Ministerio de sanidad, servicios sociales e igualdad: Madrid, Spain, 2012; pp. 1-46.

22. Liu, C.; Wang, D.; Liu, C.; Jiang, J.; Wang, X.; Chen, H.; Ju, X.; Zhang, X. What Is the Meaning of Health Literacy? A Systematic Review and Qualitative Synthesis. Fam. Med. Com. Health 2020, 8, e000351. [CrossRef]

23. Nolasco, A.; Barona, C.; Tamayo-Fonseca, N.; Irles, M.Á.; Más, R.; Tuells, J.; Pereyra-Zamora, P. Alfabetización En Salud: Propiedades Psicométricas Del Cuestionario HLS-EU-Q16. Gac. Sanit. 2020, 34, 399-402. [CrossRef]

24. Mueller, Y.K.; Monod, S.; Locatelli, I.; Büla, C.; Cornuz, J.; Senn, N. Performance of a Brief Geriatric Evaluation Compared to a Comprehensive Geriatric Assessment for Detection of Geriatric Syndromes in Family Medicine: A Prospective Diagnostic Study. BMC Geriatr. 2018, 18, 72. [CrossRef]

25. Locatelli, I.; Monod, S.; Cornuz, J.; Büla, C.J.; Senn, N. A Prospective Study Assessing Agreement and Reliability of a Geriatric Evaluation. BMC Geriatr. 2017, 17, 153. [CrossRef]

26. Sabbagh, M.; Boada, M.; Borson, S.; Chilukuri, M.; Dubois, B.; Ingram, J.; Iwata, A.; Porsteinsson, A.; Possin, K.; Rabinovici, G.; et al. Early Detection of Mild Cognitive Impairment (MCI) in Primary Care. J. Prev. Alzheimer's Dis. 2020, 7, 1-6. [CrossRef]

27. Clavería, A.; Dios-Quiroga, F.; Pallas, M.; Soliño-Lourido, S.; González-Formoso, C. Effectiveness of a multidimensional geriatric assessment (MAGICm questionnaire) in elderly patients quality of life in primary care. In Proceedings of the Programme Book of the 89th EGPRN Meeting, Vigo, Spain, 17-20 October 2019.

(C) 2020 by the authors. Licensee MDPI, Basel, Switzerland. This article is an open access article distributed under the terms and conditions of the Creative Commons Attribution (CC BY) license (http://creativecommons.org/licenses/by/4.0/). 